\title{
17. 電球形蛍光ランプの光束立ち上がり特性改善
}

\author{
安田 丈夫森山 綮與 \\ （東芝ライテック株式会社）
}

\section{1.はじめに}

近年になって電球形蛍光ランプは一段と小形化が進み 1), 需要も拡大している.しかしながら同時 に発光管の径が細い割には放電長が長いため, 点灯後の光束立ち上がり特性に課題が生じた. その現 象理解と改善方策の一環として, 報告者らは消灯中の管内水銀蒸気圧の測定 ${ }^{2}$, , 点灯後の水銀の拡散 と吸着につき計算と実験の結果 1)を報告してきた。今回は点灯後の立ち上がり特性につき CCD カメ ラを用いた測定と結着剤を変えた曲げ方式試作発光管 の光束立ち上がり特性実験により, 既報告 1)をサポー トする結果が得られたので発表する.

\section{2. 実験方法}

(1)図 1 に示すような内径 $4 \mathrm{~mm}$ の絞りと枝管をつけた 内径 $8.5 \mathrm{~mm}$ のガラス管内壁に希土類蛍光体を叙布し, 主アマルガムは Bi-In 系, 補助アマルガムは SUS に In メッキしたものとし, 希ガスに Ar530Pa を封入した 蛍光ランプを試作. $1 \mathrm{~h}$ エージングと $24 \mathrm{~h}$ 消灯留め置 きした後に, 周囲温度 $25^{\circ} \mathrm{C}$, ランプ電流 $220 \mathrm{~mA}(55 \mathrm{kHz}$ の略正弦波）で点灯し， $3 \mathrm{~s}$ おきに $436 \mathrm{~nm}$ 放射強度を CCD カメラで測定した.

(2)文献 1)に示した電球形蛍光ランプの発光管におい て 3 本のU字形状のチューブを封止端部で接続し, 見 かけ上 1 本のチューブを曲成したものと同等の形状と した. 放電長は約 $270 \mathrm{~mm}$, 管内径 $8.5 \mathrm{~mm}$, 封入アマ ルガム, 希ガス, エージングと消灯留め置き条件は実 験(1)と同等である. 管内壁には希土類蛍光体を塗布 したが, その結着剤として: a)BET 值 $100\left(\mathrm{~m}^{2} / \mathrm{g}\right)$ の比 表面積で蛍光体に対して重量比 $2 \%$ で混合した $\gamma$-ア ルミナと,b) 蛍光体に対して重量比 $2.5 \%$ で混合した ボレート系とした。

3. 結果. 考察

(1)図 2 に実験 1 の結果を示すが，436nm の強度はラ ンプ両端から先に上昇し, 管の中央部は絞りと枝管の 影響で $\mathrm{Hg}$ 蒸気圧の上昇が遅く, 従って $436 \mathrm{~nm}$ の強度 上昇も停滞している様子が伺える.

(2)図 3 は文献 1)に示した光束立ち上がりの計算結果, 図 4 は今回の実験結果である. 実験結果では相対光束 が 100\%に至る時間が遅いものの, 結着剤を $\gamma$ ーアル ミナにすると蛍光体層における $\mathrm{Hg}$ 吸着が大きく, ボ レートにすると $\mathrm{Hg}$ 吸着は小さくなると解釈すること で, 図 3 の計算結果と相関が取れる.

\section{参考文献}

1) T.Yasuda et.al.:"The Self-Ballasted CFL of an A60 Bulb Shape",J.Light \& Vis.Env. Vol.24,No.2,pp.1-7(2000)

2)安田:「アマルガム封入蛍光ランプの管内水銀蒸気圧

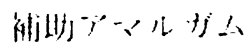

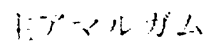

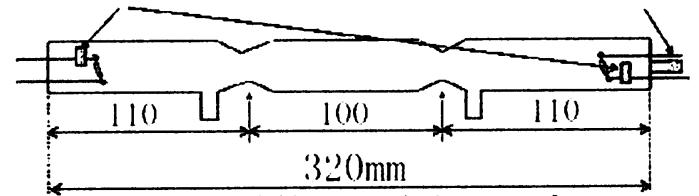

図

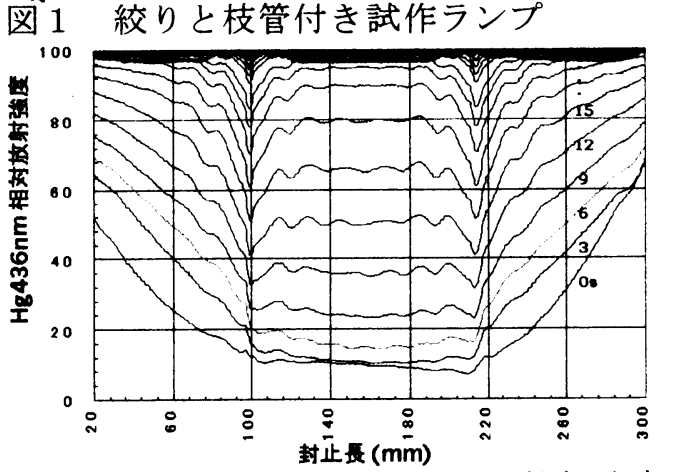

図 2 ランプ部位ごとの $436 \mathrm{~nm}$ 放射強度

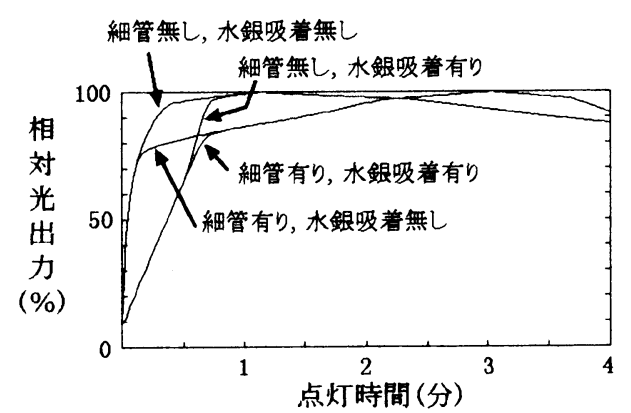

図 3 光束立ち上がりの計算結果

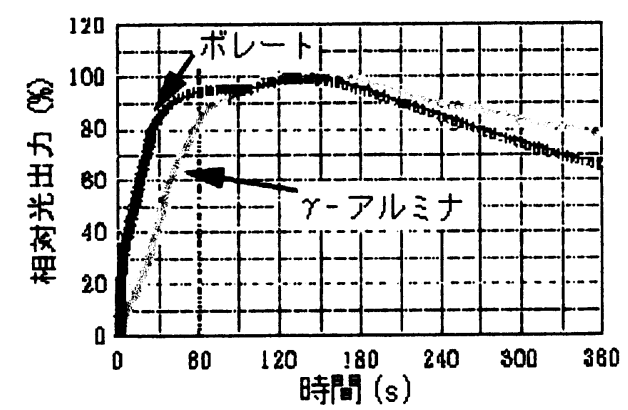

図 4 光束立ち上がりの実験結果 の測定」, 照学全大, No.7(2000)

Improvement of the run-up characteristics of self-ballasted compact fluorescent lamps, Takeo Yasuda and Takayoshi Moriyama 